\title{
The Use of Clay as Potassium Permanganate Carrier to Delay the Ripening of Raja Bulu Banana
}

\author{
Edi Santosa ${ }^{1}$, Winarso D. Widodo ${ }^{1}$ and Kholidi $^{2}$ \\ Received 11 October 2010/Accepted 18 March 2010
}

\begin{abstract}
The objective of this experiment was to study the usage of clay as potassium permanganate $\left(\mathrm{KMnO}_{4}\right)$ carrier during storage of banana var. Raja Bulu. A $1,000 \mathrm{~g}$ air-dried-clay was incorporated well with $500 \mathrm{ml}$ aquadest, added with $100 \mathrm{ml} \mathrm{KMnO}_{4}$ solution (75\%) made into paste. After air dried for 24 hours and then the powder was put in cheese cloth. Three different amount of clay powder were used as treatment, i.e., $10 \mathrm{~g}, 30$ and $50 \mathrm{~g}$ for six fingers of banana with three replicates. Results showed that clay powder effective as $\mathrm{KMnO}_{4}$ carrier for storage of banana var. Raja Bulu. Level of clay powder 30 and $50 \mathrm{~g}$ significantly increased banana shelf life as indicated by skin color and hardness by 18 days after treatments, as compared to the control. Application of 30 $g$ clay powder resulted in optimum banana storage as compared to other treatments. This experiment indicates that clay powder is promising as $\mathrm{KMnO} 4$ carrier.
\end{abstract}

Key words: absorber, clay powder, post harvest, potassium permanganate, Raja Bulu

\section{INTRODUCTION}

Banana (Musa paradisiacal L.) is one of important fruits in Indonesia. By the year of 20062008 , total annual banana production was nearly 5 million ton, but accounted $0.1 \%$ was exported (Deptan, 2008) from total acreage ca 1 million ha. The low export of bananas particularly due to low quality of fruits. Recently, eight leading varieties from 275 local varieties are commercially planted widely (Deptan, 2008), i.e., var Cavendish, var Ambon, var Raja, var Tanduk (plantain), var Emas, var Barangan, var Kepok and var Uli. High diversity of variety planted in the farmer field causes complexity in handling and marketing.

In term of food security for rural villages, banana becomes important food compared to food derived from roots and tuber because it is available throughout the year. Banana has no indication to cause allergy, easy to serve and rich of vitamins and minerals. Raja Bulu Banana has a substantial nutrient content compared to other desert bananas mainly on thiamin, riboflavin, pyridoxine, vit $\mathrm{C}$ and calcium content (CTFS, 2005). Therefore, Indonesian government through the Ministry of Research and Technology nominated banana as national commodity and intensively investigated under the scheme of National Strategic Research (RUSNAS) managed by the Center for Tropical Fruit Studies, Bogor Agricultural University.

Raja Bulu banana is one of commercial bananas ( $\mathrm{AAB}$ ) that is usually consumed both as a desert and fried banana (called as pisang goreng). Since the production area is patchy among farmer's lands and among regions, post harvest loss is high, ranging of $20-30 \%$. Banana is a climacteric fruit as indicated by marked increase of respiration rate and ethylene production during ripening process (Turner, 1997), causing low storage ability under normal condition. Banana easily deteriorates as indicated by changing of peel color, lost of weight, and lost firmness a few days after harvesting. Prabawati et al. (1991) pointed out that to improve banana quality, application of postharvest treatment is very important.

Many research have been conducted to increase var. Raja Bulu storage basically using ethylene absorber, where potassium permanganate $\left(\mathrm{KMnO}_{4}\right)$ is effective compared to commercially ethylene binders $\mathrm{CaO}$ and $\mathrm{CaCl}_{2}$ (Sambeganarko, 2008). Sholihati (2004) stated that application of $\mathrm{KMnO}_{4}$ as ethylene absorber significantly inhibited banana yellowing, maintained flavor by up to 15 days under ambient temperature $\left(28{ }^{\circ} \mathrm{C}\right)$ and prolonged the shelf life of the fruit by up to 45 days at $13{ }^{\circ} \mathrm{C} . \mathrm{KMnO}_{4}$ is strong oxidator to ethylene which forms ethylene glycol and manganese dioxide (Hein et al., 1984). For storage in Indonesian banana, direct application of $\mathrm{KMnO}_{4}$ solution is not desirable because it tints peel color into blue, therefore, $\mathrm{KMnO}_{4}$ is applied within a carrier. Pantastico (1986) recommended using carrier which has low density, low absorbent, and inert to $\mathrm{KMnO}_{4}$. For small scale farmers, the carrier should be available in local markets, abundant and low cost preferably cheap.

\footnotetext{
${ }^{1}$ Lecturer of Department Agronomy and Horticulture - Faculty of Agriculture - Bogor Agricultural University

J. Meranti Kampus IPB Darmaga, Bogor 16680 Telp/Fax (0251) 8629353, Email: editodai@yahoo.com

(*Corresponding authors)

${ }^{2}$ Alumnus of Department Agronomy and Horticulture
} 
Many materials have been evaluated such as charcoal, floating stone and sawdust (Jannah, 2008), and zeolite (Sholihati, 2004; Jannah, 2008) to prolong banana storage. Jannah (2008) pointed out that using zeolite as carrier of $\mathrm{KMnO}_{4}$, banana quality was kept 7 days longer compared to the control, while Sholihati (2004) recommended using pellet of charcoal where it prolonged up to 15 days. Charcoal causes black tint on banana peel. Furthermore, Jannah (2008) stated that zeolite as $\mathrm{KMnO}_{4}$ carrier had a similar effectiveness to the commercial ethylene binders; however, zeolite mineral is relatively more expensive for farmers compared to clay. Clay is easily found in Indonesia and very cheap compared to commercial ethylene binders as well as previous material evaluated. The objective of this research was to study the effectiveness of clay as a carrier for $\mathrm{KMnO}_{4}$ in binding ethylene gas-in order to decelerate the ripening process of Raja Bulu banana fruits during storage.

\section{MATERIALS AND METHODS}

This Research was conducted from July to August 2009 at Postharvest Laboratory of the Center for Tropical Fruit Studies (CTFS), Bogor Agricultural University (IPB), Bogor, Indonesia. Banana bunches were collected from the plants which were grown and applied with $300 \mathrm{~kg} \mathrm{~N}$ (urea), $500 \mathrm{~kg}$ potassium $\left(\mathrm{K}_{2} \mathrm{O}\right)$ and $200 \mathrm{~kg}$ phosphorus $\left(\mathrm{P}_{2} \mathrm{O}_{5}\right)$ at the university experimental farm (approximately $250 \mathrm{~m}$ above sea level). At planting, the banana seedling was treated with commercial biological control for Fusarium and manure of goat at the rate of $10 \mathrm{~kg} /$ plant. Water table was $60 \mathrm{~cm}$ below soil surface. Maintenance procedures followed banana standard operating procedure (SOP) released by CTFS (2008).

Bunch of banana var. Raja Bulu was collected at optimum maturity indicated by green color and had sharp-peel fruit fingers. The fruits were cleaned manually and wiped carefully-by moist cheese cloth. The fruit fingers had firmness value about 0.80 $\mathrm{kg} /$ second, edible portion $41.85 \%$ and total acid $20.56 \mathrm{mg} / 100 \mathrm{~g}$. Hands of fruit were sorted and any damages and wounds were discharged. For local marketing objective, an original hand (ca 12-14 fingers) was cut using sterile knife into two pieces and trimmed so that each hand contained six fingers.
Total weight of the six fingers ranged from 420-670 g.

Clay was obtained from IPB Campus, Darmaga-Bogor collected during dry season and used as $\mathrm{KMnO}_{4}$ carrier (Fig.1.a). The clay contained $\mathrm{N}$ total $(0.09 \%)$, medium phosphorus availability (18.0 ppm), total exchangeable cation $(80 \%)$ and medium potassium availability $(17.0 \mathrm{ppm})$. The clay had $\mathrm{pH}$ 6.5. Prior application, $1,000 \mathrm{~g}$ air-dried-clay was incorporated well with $500 \mathrm{ml}$ aquadest and then added with $100 \mathrm{ml} \mathrm{KMnO}_{4}$ solution $(75 \%$ ) made into paste. The paste was then flattened as a layer with the thickness of $1-2 \mathrm{~cm}$ and then dried in room temperature for 24 hours. The dried-flatened paste contained $\mathrm{KMnO}_{4}$ was then milled into powder and the powder was inserted into cheese cloth sachet sized $5 \mathrm{~cm} \times 5 \mathrm{~cm}$ (Fig.1.b). The different rates of powder was applied, namely $10 \mathrm{~g}, 30 \mathrm{~g}$ and $50 \mathrm{~g}$ for six fingers. The experiment was replicated three; control was prepared without any clay treatment. Experiment was arranged in randomized complete block design.

Fingers of banana were kept in a transparent plastic bag, six fingers for a $10 \mathrm{~kg}$ plastic bag. A silica gel (ca $10 \mathrm{~g}$ ) to absorb excess water was added in each plastic bag. Then, the bags were arranged inside cartoon sized $45 \mathrm{~cm} \times 25 \mathrm{~cm} \times 10 \mathrm{~cm}$ and filled with paper (Fig.1.c) according to Nugraheni (2006) and Diennazola (2008). One carton was filled with three plastic bags, then it was stored at room temperature $\left(27-30{ }^{\circ} \mathrm{C}\right)$ (Fig. 1.d). The carton then sealed until observation.

Observation was conducted on daily basis up to 18 days after treatment (DAT) for color indices, texture, soluble solid, total acid, and weight. Color indices adopted Catalytic generator LCC 2006 and Turner (1997) represented by 1 to 8 grades, i.e., 1 green, 2-green with light yellow, 3-green yellowish, 4-yellow with light green, 5-yellow with green at finger tip, 6-yellow, 7-yellow with light brown spot, and 8-yellow with wider brown spot. Total acid was measured from $50 \mathrm{~g}$ banana flesh grinded with 200 $\mathrm{ml}$ with aquadest. Total acid was measured by titration using phenolphthalein to a $25 \mathrm{ml}$ filtrate then neutralized with $\mathrm{NaOH} 0.1 \mathrm{~N}$ until the solution became light red. Fruit texture was measured using hand penetrometer at half tip, middle and half lower part of finger. Hand refractometer, was used to monitor total soluble solid. Banana flesh was grinded and sap was collected using cheese cloth. Total soluble solid was indicated by obrix. Statistical analysis was conducted using SPSS software. 


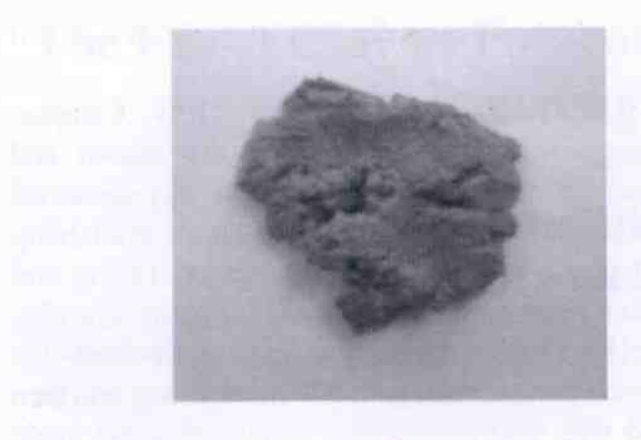

a

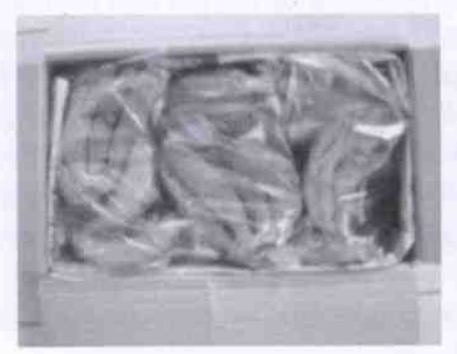

c

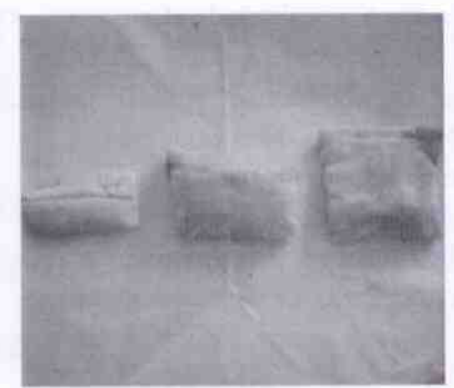

b

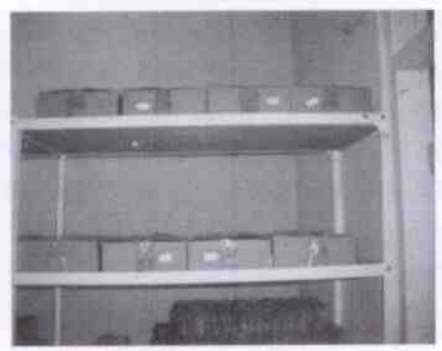

d

Fig.1. Clay soil used in this experiment as carrier of $\mathrm{KMnO}_{4}$ : (a) clay powder contained $\mathrm{KMnO} 4$ placed in cloth bag, (b) banana hand kept inside plastic bag and arranged in the carton box- (c) and stored at room temperature (d).

\section{RESULT AND DISCUSSION}

\section{Peel Color}

Application of clay powder containing $\mathrm{KMnO}_{4}$ significantly postponed the yellowing of banana peel. Fig. 2 shows that before 15 days, there was difference for 30 and $50 \mathrm{~g}$ treatment of clay powder level as compared to control. Clay powder at level of $50 \mathrm{~g}$ per bag enabled to maintain banana peel greenish yellow (score index 5) at by up to 21 days DAT. Treatment with $30 \mathrm{~g}$ clay powder enabled to maintain banana peel at score index 5 until 18 DAT. This finding was in line with Sambeganarko (2008) finding where application of $\mathrm{KMnO}_{4}$ enabled to prolong banana shelf life more than 15 days.

Consumers prefer yellow peel banana (score index 6), therefore, application of $\mathrm{KMnO}_{4}$ through clay powder as carrier is useful to prolong storage of banana var. Raja Bulu. Fig.2 indicates that application of clay powder of 10 and $30 \mathrm{~g}$ were effective to maintain peel color of banana and accepted able by consumer for 18 days while higher level of clay powder, $50 \mathrm{~g}$, extended to 21 days.

\section{Weight loss}

Minimum weight loss during storage is preferable for banana, since fruit weight loss tended to increase by time of storage due to respiration (Mikasari, 2004). Fig.3. indicated that the weight loss of bananas increased during storage. Marked weight loss occurred within 9 DAT for control and $10 \mathrm{~g}$ clay powder treatments, e.g., reached approximately $10 \%$. Treatments of 30 and $50 \mathrm{~g}$ clay powder minimized weight loss up to 18 DAT. After 18 DAT, all treatments showed marked increase of weight loss, irrespective of levels of the clay powder. However, the rate of weight loss was likely inconsistent. Variation on moisture content inside plastic bag might correlate with the difference rate of the weight loss.

In this experiment, a $10 \mathrm{~g}$ silica gel had prepared to absorb moisture. Raja Bulu banana probably released large moisture during storage that implied to high weight loss. Hein et al. 
(1984) reported that ethylene reduction by $\mathrm{KMnO}_{4}$ is affected by level of moisture inside storage bag. Therefore, for future research, it is important to control the excess moisture during storage of banana to increase effectiveness of $\mathrm{KMnO}_{4}$ treatment.

Tursiska (2007) pointed out that without chemical treatment, weight loss in banana var Raja Bulu storage was ca $22 \%$. Base on peel appearance of the Raja Bulu banana, consumer still appreciate in high price when weight loss below $5 \%$. Increase in weight loss is usually followed by lack of peel appearance; therefore, control moisture during storage is important. In this experiment, treatments of clay powder 30 and $50 \mathrm{~g}$ minimize weight loss below $5 \%$ within 18 DAT (Fig.3).

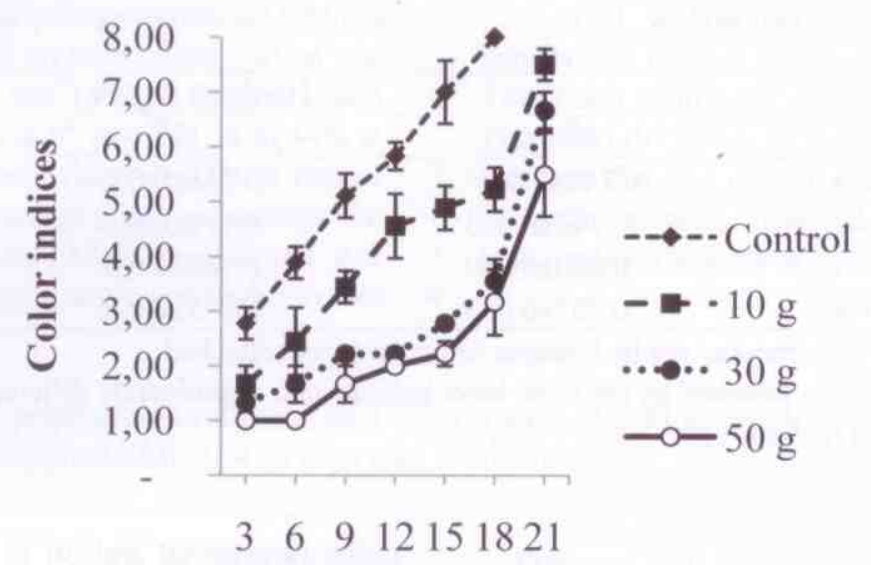

Days after treatment

Fig. 2. Color indices of banana var, Raja Bulu peel from different clay powder level.

No data was obtained from control treatment at 21 DAT due to the banana had deteriorated. Bars \pm S.E.

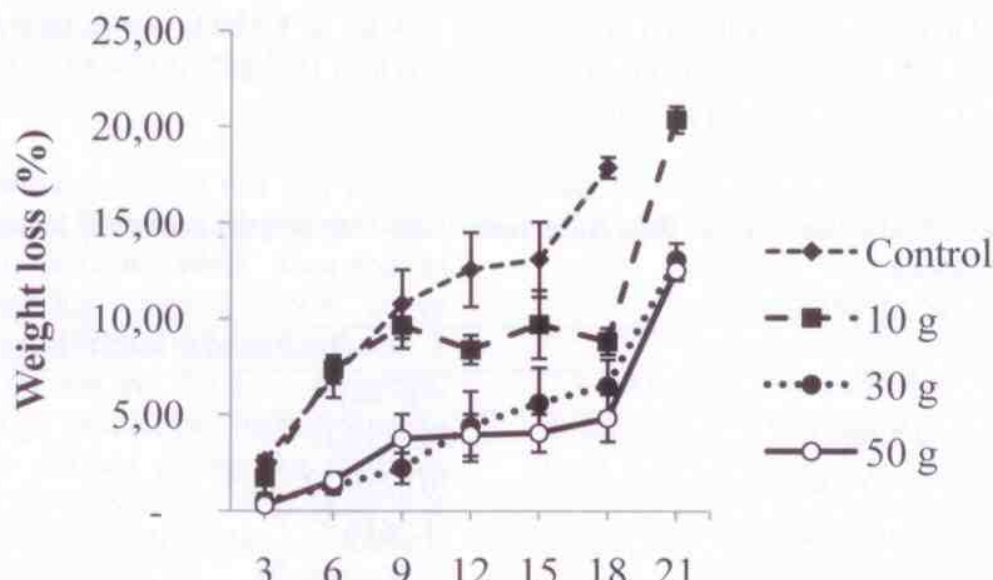

Days after treatment

Fig.3. Percentage of weight loss during storage Banana var. Raja Bulu treated with clay powder contained $\mathrm{KMnO}_{4}$. No data was obtained from control treatment at 21 DAT due to the banana had deteriorated. Bars \pm S.E. 


\section{Hardness}

Banana hardness decreased by time after harvest (Table 1), and deteriorated after 21 DAT for control and 23 days for other treatments. Table 1 shows that treatment of 10 and $30 \mathrm{~g}$ clay powder containing $\mathrm{KMnO}_{4}$ significantly increased banana hardness compared to control particularly at $6^{\text {th }}$ day after treatment. In general, application of clay powder tended to increase banana hardness for less than 12 DAT, irrespective of treatment. Application of clay powder at rate $30 \mathrm{~g}$ maintained longer hardness of banana, where the hardness decreased approximately $5 \%$ during storage. Moreover, preference test for banana treated with $30 \mathrm{~g}$ clay powder was still acceptable.

Table 1. Hardness of banana var. Raja Bulu treatd by clay powder contained $\mathrm{KMnO}_{4}$ at 6,12 and 18 days of storage at room temperature

\begin{tabular}{|c|c|c|c|c|c|}
\hline \multirow{2}{*}{ Treatment $^{x}$} & & & Hardness $(\mathrm{kg} / \mathrm{sec})^{2}$ & \multirow{2}{*}{\multicolumn{2}{|c|}{$18^{\text {th }}$}} \\
\hline & $6^{\text {th }}$ day & & $12^{\text {th }}$ & & \\
\hline Without KMnO4 & $0.740 \pm 0.015^{y}$ & b & $0.713 \pm 0.009^{\mathrm{a}}$ & $0.623 \pm 0.033$ & b \\
\hline $10 \mathrm{~g}$ clay powder & $0.793 \pm 0.003$ & a & $0.710 \pm 0.006^{\mathrm{a}}$ & $0.660 \pm 0.030$ & $a b$ \\
\hline $30 \mathrm{~g}$ clay powder & $0.800 \pm 0.000$ & a & $0.760 \pm 0.020^{\mathrm{a}}$ & $0.760 \pm 0.012$ & a \\
\hline $50 \mathrm{~g}$ clay powder & $0.763 \pm 0.013$ & ab & $0.733 \pm 0.026^{\mathrm{a}}$ & $0.713 \pm 0.012$ & $a b$ \\
\hline
\end{tabular}

${ }^{\mathrm{z}}$ Measured using hand penetrometer applied banana finger with peel attached

${ }^{y}$ Values in the same column followed by the same letter indicate non significantly different after Tukey $5 \%$

${ }^{\mathrm{x}}$ Clay powder contained $\mathrm{KMnO}_{4} 75 \%$; Mean \pm S.E.

\section{Total Soluble Solid}

Total soluble solid (TSS) reflects the taste after harvest, where higher value indicates sweeter than the lower. As a climacteric fruit, sugar content of banana increases in the ripening stage up to reach optimum value before consumed (Mattoo et al., 1989; Robinson, 1999) due to decreasing phenolic compounds. Table 2 indicates that application of clay powder, irrespective of its level, significantly retained increasing TSS at 12 DAT; application of clay powder 10 and $30 \mathrm{~g}$ being significantly had lower TSS than control at 12 DAT, but did not different significantly with $50 \mathrm{~g}$. This finding is in line with result of Diennazola (2008). At 18 DAT, TSS content did not significantly different among treatments, although, application of clay powder tended to have lower TSS content than control ones. It indicated that effectiveness of treatment using clay powder as $\mathrm{KMnO}_{4}$ carrier to maintain low TSS is less than 18 days.

Table 2. Total soluble solid of banana var. Raja Bulu treated with clay powder contained $\mathrm{KMnO}_{4}$ at 6,12 and 18 days after storage

\begin{tabular}{|c|c|c|c|}
\hline & \multirow{2}{*}{ Treatment $^{x}$} & \multicolumn{2}{|c|}{ Total soluble solid ( ${ }^{\circ}$ brix $)^{2}$} \\
\hline & & $12^{\text {th }}$ day & $18^{\text {th }}$ day \\
\hline \multirow{4}{*}{4} & Without $\mathrm{KMnO}_{4}$ & $24.61 \pm 0.18^{a}$ & $27.17 \pm 0.42^{a}$ \\
\hline & $10 \mathrm{~g}$ clay powder & $20.52 \pm 0.79^{b}$ & $25.25 \pm 0.98^{a}$ \\
\hline & 30 g clay powder & $21.26 \pm 0.87^{b}$ & $23.33 \pm 0.85^{a}$ \\
\hline & $50 \mathrm{~g}$ clay powder & $23.06 \pm 0.61^{a b}$ & $23.34 \pm 1.19^{\mathrm{a}}$ \\
\hline
\end{tabular}

${ }^{\mathrm{z}}$ Measured on for banana flesh after peeling

${ }^{y}$ Value in the same column followed by similar alphabet indicated non significantly different after Tukey $5 \%$.

${ }^{x}$ Clay powder contained $\mathrm{KMnO}_{4} 75 \%$; Mean \pm S.E. 
Edible Portion, Pulp/Peel Ratio and Total Titratable Acid

Edible portion and pulp/peel ratio tended to increase by time of storage (data not shown). The increase in edible portion and pulp/peel ratio might relate to the lots of moisture of the peel. Hassan and Pantastico (1990) stated that pulp to peel ratio differences during storage was caused by increasing sugar content of pulp and then mobilized the water from the peel.

Application of clay powder contained $\mathrm{KMnO}_{4}$ had no significant affect on both edible portion and pulp/peel ratio at 6,12 and 18 days. Edible portion ranged from 36 to $44 \%$ at $6^{\text {th }}$ day and 38 to $44 \%$ at $12^{\text {th }}$ DAT; while pulp/peel ratio constant at ranged from 0.6 to 0.8 during storage (data not shown). On the contrary, Diennazola (2008) pointed out that treatment of $\mathrm{KMnO}_{4}$ significantly had higher edible portion at 6 and 12 DAT ca. $50 \%$ higher than control treatment. After 18 days of storage, no significant different was observed among treatment on pulp/peel ratio and edible portion (Table 3 ). This experiment indicated that application of $\mathrm{KMnO}_{4}$ did not affect pulp/peel ratio and edible portion of banana var. Raja Bulu. It is probably that storage using plastic bag as a model of modified atmosphere protect moist lost from the banana as indicated by Prabawati et al. (1991), causing similar not significant response to $\mathrm{KMnO}_{4}$ treatments.

Acid content increased during storage of banana and then slightly decreased after fully ripe. This result is in line with finding by Santoso and Purwoko (1995), due to the acid degradation. Table 3 indicates that acid content was significantly lower at $30 \mathrm{~g}$ clay powder treatment as compared to other treatments particularly at 18 days after treatment.

Table 3. Edible portion, pulp/peel ratio and total acid of banana var. Raja Bulu threatened with different amount of clay powder contained $\mathrm{KMnO}_{4}$ at 18 days after treatment

\begin{tabular}{cccc}
\hline Treatment & Edible portion $(\%)$ & Pulp/peel ratio & $\begin{array}{c}\text { Total titratable acid } \\
(\mathrm{mg} / 100 \mathrm{~g})^{\mathrm{z}}\end{array}$ \\
\hline Control without $\mathrm{KMnO}_{4}$ & $41.1 \pm 2.3^{\mathrm{a}}$ & $0.75 \pm 0.08^{\mathrm{a}}$ & $30.75 \pm 0.18^{\mathrm{a}}$ \\
10 g clay powder $^{\mathrm{a}}$ & $39.8 \pm 2.1^{\mathrm{a}}$ & $0.71 \pm 0.05^{\mathrm{a}}$ & $29.16 \pm 0.36^{\mathrm{a}}$ \\
30 g clay powder & $39.8 \pm 4.9^{\mathrm{a}}$ & $0.69 \pm 0.14^{\mathrm{a}}$ & $25.24 \pm 0.64^{\mathrm{b}}$ \\
50 g clay powder & $43.9 \pm 2.2^{\mathrm{a}}$ & $0.69 \pm 0.07^{\mathrm{a}}$ & $30.93 \pm 0.41^{\mathrm{a}}$ \\
\hline
\end{tabular}

${ }^{2}$ Measured for banana pulp after peel

${ }^{y}$ Value in the same column followed by similar alphabet indicated non significantly different after

Tukey $5 \%$; Mean \pm S.E.

${ }^{x}$ Clay powder contained $\mathrm{KMnO}_{4} 75 \%$

This experiment showed that clay powder could be used as carrier $\mathrm{KMnO}_{4}$. Clay powder could absorb all $\mathrm{KMnO}_{4}$ solution, while according to Jannah (2008), sawdust, floating stone, active charcoal and zeolite absorbed $\mathrm{KMnO} 4$ solution 3 times, 0.3 times, 0.4 times and 0.1 times of weight, respectively. Although sawdust had highest capacity to absorb $\mathrm{KMnO} 4$ solution among the materials tested by Jannah (2008), however, it is likely that presence of organic compounds might bond $\mathrm{KMnO}_{4}$ causing low capability on ethylene absorption. On the other hand, free organic compound and neutral chemical properties of clay and the powdered-form increase the effectiveness of clay to absorb ethylene, eventhough the absorbance is lower than sawdust. It needs further investigation to understand the mechanism of clay powder related to capacity to absorb ethylene. In the future, mass production of clay powder as $\mathrm{KMnO}_{4}$ is promising as cheap and affordable material for rural farmers.

\section{CONCLUSION}

Application of clay powder as $\mathrm{KMnO}_{4}$ carrier is effective for prolong storage banana var. Raja Bulu. Application of clay powder at rate $30 \mathrm{~g}$, equal to $30 \mathrm{~g} / \mathrm{kg}$ fresh banana is desirable to maintain banana storage for 18 days. To control storage moisture should be investigated in the next experiment since this may promote peel decay, as this has been indicated by previous research.

\section{ACKNOWLEDGEMENT}

The authors would like to thank Center for Tropical Fruit Studies (CTFS), Bogor Agricultural 
University for facilitating this experiment. This experiment was funded by National Strategic Research on Tropical Fruit (RUSNAS) granted through CTFS for first author 2007 to 2009. Thanks are also due to Ms. Sulasih and other CTFS staffs who assisted the observation.

\section{REFERENCES}

CTFS. 2005. Final report National Strategic Research on Fruits: Banana. Lembaga Penelitian dan Pemberdayaan Masyarakat. Bogor. 200 p. (In Indonesian-unpublished).

Deptan. 2008. National fruit production 2000-2009. http://www.deptan .go.id/. Department of Agriculture, Republic of Indonesia. [Accessed at 4 May 2009]. (In Indonesian).

Diennazola, R. 2008. Effect of filler in storage box to shelf life and quality of banana var Raja Bulu. Undergraduate Thesis. Department of Agronomy and Horticulture, Faculty of Agriculture, Bogor Agricultural University. Bogor-Indonesia. 49 p. (In Indonesianunpublished).

Hassan, A., Er. B. Pantastico. 1990. Banana. Asean Food Handling Bureau. Malaysia. 147 p.

Hein, M., L.R. Best, S. Pattison. 1984. College Chemistry and Introduction to General Organic and Biochemistry $3^{\text {rd }}$ ed. Brooks/Cole Publ. Co. California. 770 p.

Jannah, U. F. 2008. Effect of potassium permanganate absorber on storage of banana var. Raja Bulu. Undergraduate Thesis. Department of Agronomy and Horticulture, Faculty of Agriculture, Bogor Agricultural University. Bogor-Indonesia. 48 p. (In Indonesian-unpublished).

Mattoo, A. K., T. Murata, Er. B. Pantastico, K. Chachin, K. Ogata, C. T Phan. 1989. Chemical changes during ripening. In Er. B. Pantastico (Ed.). Postharvest Physiology, Handling and Uses of Tropical Fruit and Tropical and Subtropical Vegetables. Gajah Mada University Press. Yogyakarta. Pp. 160-197 (In Indonesian).
Mikasari, W. 2004. Studies on storage and banana var Raja Bulu ripening (Musa paradisiaca var. sapientum L.) using temperature modification. Thesis. Graduate School, Faculty of Agriculture, Bogor Agricultural University. Bogor-Indonesia. 110 p. (In Indonesian-unpublished).

Nugraheni, A. 2006. Effect of storage box and filler on quality of banana var Raja Bulu. Undergraduate Thesis. Department of Agronomy and Horticulture, Faculty of Agriculture, Bogor Agricultural University. Bogor-Indonesia. 50 p. (In Indonesianunpublished).

Pantastico. Er. B., A. K. Matto, C. T. Phan. 1989. Role of ethylene on ripening. In Er. B. Pantastico (Ed.). Postharvest Physiology, Handling and Uses of Tropical Fruit and Tropical and Subtropical Vegetables. Gajah Mada University Press. Yogyakarta. Pp. 120-135. (In Indonesian).

Prabawati, S., Suryani, Sjaifullah , I.M. Dasuki. 1991. Effect of packaging using polyethylene bag with low pressure on physiology of banana var Raja Bulu during storage. J. Hortikultura 1 (4): 27-34. (In Indonesian).

Robinson, J.C. 1999. Bananas and Plantains. CAB International. London. 238p.

Sambeganarko, A. 2008. Effect of $\mathrm{KMnO}_{4}$, Ethylene Absorber, and $\mathrm{CaCl}_{2}$ on quality and storage of banana var. Raja Bulu (Musa paradisiaca L.). Undergraduate Thesis. Department of Agronomy and Horticulture, Faculty of Agriculture, Bogor Agricultural University. Bogor-Indonesia. 40 p. (In Indonesianunpublished).

Santoso, B. B. and B. S. Purwoko. 1995. Physiology and Postharvest Of Horticulture. IndonesiaAustralia Eastern Project. Ministry of Agriculture, Jakarta. 187 p.

Sholihati. 2004. Studies on potassium permanganate absorbent to prolong storage banana var Raja (Musa Paradisiaca var. sapientum L.). Thesis. Graduate School, Faculty of Agriculture, Bogor Agricultural University. Bogor-Indonesia. 177 p. (In Indonesianunpublished). 
Turner, D.W. 1997. Banana and Plantains. In S. Mitra (Ed.). Postharvest Physiology and Storage of Tropical and Subtropical Fruits. CAB International Walling Ford. UK. P 58-59.
Tursiska, S. 2007. Effect of storage temperature and time on quality of banana var. Raja Bulu after curing. Undergraduate Thesis. Department of Agriculture Machinery, Faculty of Agricultural Technology, Bogor Agricultural University. Bogor-Indonesia. 49 p. (In Indonesian-unpublished). 